\title{
MODIFIKASI SEPATU KUDA DENGAN MENAMBAH PENGAIT DAN MERUBAH BENTUK LUBANG PAKU PADA KARET SEPATU KUDA DENKAVKUD
}

\author{
Januar Redolan Ginting ${ }^{1}$, Sufiyanto ${ }^{2^{*}}$, Ardyanto $^{3}$ \\ ${ }^{1,2}$ Jurusan Teknik Mesin, Fakultas Teknik, Universitas Merdeka Malang \\ ${ }^{3}$ Jurusan Teknik Otoranpur, Poltekad \\ *Email corresponding author: sufiyanto@unmer.ac.id
}

\begin{abstract}
Abstraksi
Denkavkud merupakan satuan tempur berkuda yang ada dalam jajaran TNI AD yang menggunakan kuda sebagai alat transportasi. Prajurit sering mengalami kendala dalam mengendarai kuda pada jalan beraspal atau diperkeras. Kuda tidak bisa berjalan dan berlari secara maksimal pada medan diperkeras karena licin. Penelitian ini bertujuan untuk memodifikasi sepatu kuda dengan penambahan pengait pada sepatu kuda Denkavkud. Modifikasi ini diharapkan dapat membuat sepatu kuda tidak mudah lepas dalam keadaan medan diperkeras atau diaspal. Metode yang digunakan adalah metode eksperimen (uji dinamis) pada modifikasi desain sepatu kuda yang bertujuan untuk mendapat data karakteristik desain tersebut. Analisa kekuatan pada plat sepatu kuda dan pengujian keausan lapisan karet digunakan untuk mendapatkan hasil yang maksimal dalam proses modifikasi sepatu kuda. Pada uji dinamik, prediksi umur dari tapal kuda yang telah dimodifikasi adalah selama 36 hari. Tingkat keausan pada uji dinamik diperoleh rata-rata $0.125 \mathrm{~mm} / 15 \mathrm{~km}$. Pada pengujian keausan, prediksi umur bahan karet yang digunakan pada sepatu kuda yaitu 24 hari. Rata-rata laju keausan karet adalah 3,2 $10^{-4} \mathrm{gr} / \mathrm{m}$. Keausan yang terjadi adalah 4,65 gram / hari dengan jarak tempuh kuda $15 \mathrm{~km} /$ hari.
\end{abstract}

Kata Kunci : Modifikasi Sepatu Kuda, Pengait, Uji Dinamis

\begin{abstract}
Denkavkud is an equestrian combat unit in the Indonesian army that uses horses as a means of transportation. The soldiers often experience obstacles in riding horses on paved roads or hardened. The horses can not walk and run maximally on hardened field because it is slippery. This research aims to modify horseshoes with the addition of hooks on the Denkavkud horseshoes. This modification is expected to make the horseshoes are not easily separated in the hardened or asphalted field. The used method is experimental method (dynamic test) on the horseshoe design modification which aims to get the characteristic data of the design. Strength analysis on the horseshoe plate and rubber wear testing are used to obtain maximum results in the horseshoe modification process. In the dynamic test, the predicted age of the modified horseshoe is 36 days. The wear rate on the dynamic test is obtained an average of $0.125 \mathrm{~mm} / 15 \mathrm{~km}$. In the wear test, the prediction of the age of rubber material used in horse shoes is 24 days. The average of the rubber wear rate is $3.210^{-4} \mathrm{gr} / \mathrm{m}$. The wear that occurs is 4.65 grams / day with horse mileage $15 \mathrm{~km} /$ day.
\end{abstract}

Keywords : Modified Horseshoes, Hooks, Dynamic Test

\section{PENDAHULUAN}

Sudah sejak dahulu kala kuda telah dikenal dan dipergunakan untuk membantu pekerjaan manusia sebagai kuda tarik, tunggang dan beban. Selain dari pada itu kuda juga dipergunakan pada olah raga seperti loncat, pacu, tunggang indah dan kemampuan melewati segala bentuk medan serta daya tahan yang tinggi. Dibeberapa negara selain untuk sarana olah raga, kuda juga masih digunakan untuk tugas-tugas militer.
Seiring dengan kemajuan zaman banyak jalan dan medan yang diperkeras/aspal, maka penggunaan transportasi dengan kuda sering mengalami permasalahan pada bagian sepatu kuda. Denkavkud merupakan satuan tempur berkuda yang ada dalam jajaran TNI AD yang menggunakan kuda sebagai alat transportasi. Dalam pelaksanaan tugasnya prajurit sering mendapat tugas protokoler untuk mengawal, membawa bendera pusaka dengan berkuda dan operasi pengamanan yang menggunakan kuda. 
Pada waktu melaksanakan tugas, prajurit sering mengalami kendala dalam mengendarai kuda pada jalan beraspal atau diperkeras. Kuda tidak bisa berjalan dan lari secara maksimal pada medan diperkeras karena licin.

Penelitian terdahulu yang dilakukan oleh Sutikno (2011), telah membuat sepatu kuda dengan menggunakan bahan dari karet dengan bertujuan agar dapat menggantikan sepatu kuda konvensional menjadi lebih baik saat digunakan oleh satuan pemakai. Dari hasil pengujian dilapangan sepatu kuda yang telah dibuat masih ada kendala pada saat dilakukan pengujian. Kendala yang masih dialami oleh penguji satuan pemakai adalah sepatu kuda masih sering terlepas karena kurangnya pengait antara karet sepatu kuda dengan kuku kuda.

Permasalahan yang terjadi diatas tersebut diharapkan dapat diatasi dengan modifikasi sepatu kuda yang dibuat dari bahan karet dengan menambah pengait dan merubah bentuk lubang paku sepatu kuda. Sehingga pada waktu melewati medan diperkeras atau aspal kuda tidak mudah terpeleset dan sepatunya tidak lepas pada saat digunakan.

Sehubungan dengan hal tersebut diatas maka akan dilakukan penelitian untuk memodifikasi sepatu kuda tersebut dengan penambahan pengait pada karet sepatu kuda Denkavkud. Modifikasi ini diharapkan dapat membuat sepatu kuda yang sudah ada dari bahan karet lebih baik saat digunakan dan tidak mudah lepas dalam keadaan medan diperkeras atau aspal.
Permasalahan yang akan dibahas antara lain :

a. Melakukan redesain pada sepatu kuda dengan pelapis karet dengan penambahan pengait dan merubah bentuk lubang sepatu kuda.

b. Melakukan pengujian dinamis dan keausan karet.

c. Menganalisa kekuatan paku dan plat besi sepatu kuda

\section{KAJIAN PUSTAKA}

Di satuan kavaleri tanpa adanya sepatu kuda, prajurit sering mengalami kendala dalam mengendarai kuda pada saat jalan, lari dan melewati rintangan. Kuda tidak bisa berjalan dan lari secara maksimal apabila sepatu kuda dalam pemakaian tidak benar, oleh karena itu sepatu kuda sangat berperan pada kaki kuda.

Ketahanan gerak kuda merupakan yang terpenting bagi kesatuan Kavaleri berkuda untuk membantu tugas yang dilakukan. Dalam gerak kuda, diperlukan sepatu kuda yang kuat untuk menopang tubuh dan pengendaranya. Sepatu kuda yang digunakan haruslah kuat dan tahan lama. Penggunaan sepatu kuda yang kurang tepat akan berakibat fatal baik bagi kuda maupun pengendaranya. Untuk itu, sangat penting diteliti desain dan ketahanan sepatu kuda yang kuat dan tahan lama serta dapat digunakan diberbagai kondisi medan.

Berikut kondisi fisik kuda di Yonkav 3/Tank yang digunakan dalam penelitian untuk pengujian dinamis.. 


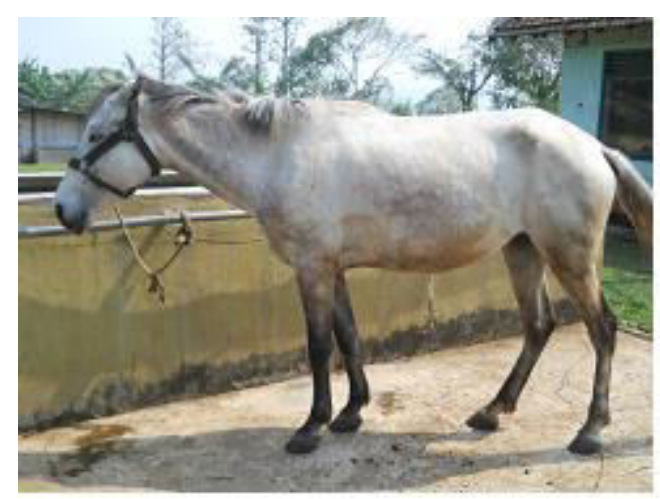

Gambar 1. Kuda Yonkav 3/Tank

Kuda tersebut adalah persilangan kuda Australia, digunakan oleh pasukan Yonkav 3/Tank sebagai alat latihan kendaraan tempur.

\section{METODOLOGI PENELITIAN}

Tujuan dalam pelaksanaan penelitian ini adalah untuk mengetahui data-data kemampuan fisik dan karakteristik karet sepatu kuda. Setelah diketahui data-datanya sehingga dapat dilaksanakan perencanaan dan karateristik sepatu kuda. Metode yang digunakan dalam penelitian ini adalah metode eksperimen nyata di lapangan, yang bertujuan untuk mendapat data karakteristik karet sepatu kuda pada modifikasi desain sepatu kuda sehingga desain tersebut mampu digunakan sesuai dengan tujuan.

Berikut diagram alir pada penelitian ini:

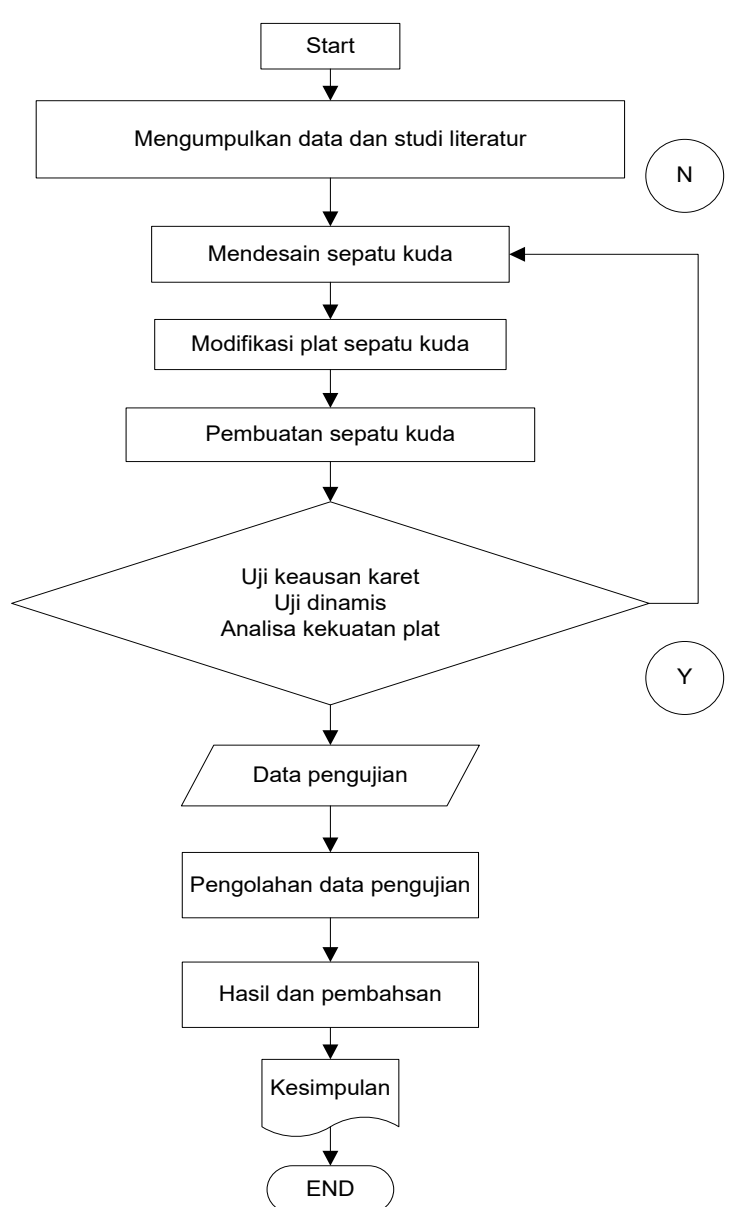

Gambar 2. Diagram Alir Penelitian

Dalam perencanaan pembuatan karet sepatu kuda diharapkan memiliki kekuatan dan kualitas yang lebih baik. Modifikasi sepatu kuda tersebut diharapkan dapat membuat sepatu kuda kuat dan tahan lama. Proses ini dimulai dari menentukan tempat penelitian, pemilihan bahan yang akan direncanakan, alat ukur yang digunakan, desain sepatu kuda dan prosedur penelitian.

\section{Tempat Penelitian}

Adapun tempat pelaksanaan penelitian adalah sebagai berikut :

1. Lembaga Pengkajian Teknologi Angkatan Darat. 
2. Yonkav 3/Tank Kodam V/Brawijaya, merupakan satuan Batalyon Kaveleri yang berada di Malang.

3. Universitas Merdeka Malang, Sebagai tempat pengujian keausan karet sepatu kuda yang digunakan.

4. Bengkel bubut, yang berada di bululawang sebagai tempat pembuatan kerangka besi sepatu kuda yang digunakan.

\section{Variabel Penelitian}

Adapun variabel yang diukur dalam penelitian ini adalah :

\section{a. Uji dinamis.}

1) Variabel bebas :

- Beban Kuda (kg)

- Jarak tempuh $(\mathrm{km})$

2) Variabel terikat :

- Tebal lapisan karet dalam kondisi terpakai (mm)

b. Uji Keausan.

1) Variabel bebas :

- Beban tekan $(\mathrm{kg})$

- Lama pengujian (menit)

- Kecepatan putaran (rpm)

2) Variabel terikat :

- Berat yang hilang (gram)

- Laju keausan (gram/meter)

\section{HASIL DAN PEMBAHASAN}

Dari hasil perhitungan analisis dan data hasil pengujian yang telah dilakukan dapat digunakan sebagai acuan dalam proses perencanaan modifikasi sepatu kuda. Hal ini bertujuan agar sepatu kuda yang dimodifikasi mampu menerima beban kuda yang diaplikasikan pada sepatu kuda.

\section{Hasil Modifikasi Sepatu Kuda}

Sepatu kuda yang telah dimodifikasi sesuai dengan perencanaan dan telah diuji cobakan untuk mengetahui kekuatannya. Hasil modifikasi sepatu kuda dapat dilihat sebagai berikut:

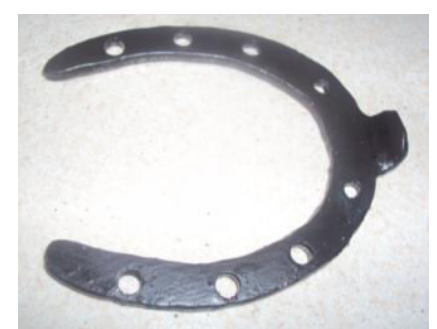

Gambar 3. Kerangka Besi Modifikasi Sepatu Kuda

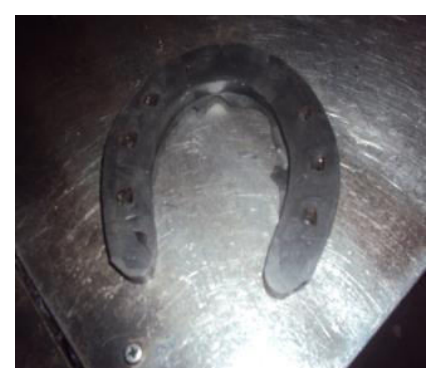

Gambar 4. Hasil Modifikasi Sepatu Kuda Setelah Di Lapisi Karet (Sebelum Dilakukan Finishing)

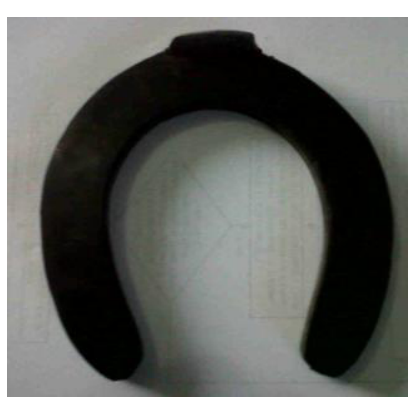

Gambar 5. Tampak Atas Hasil Modifikasi Sepatu Kuda Setelah Di Lapisi Karet (Setelah Dilakukan Finishing) 


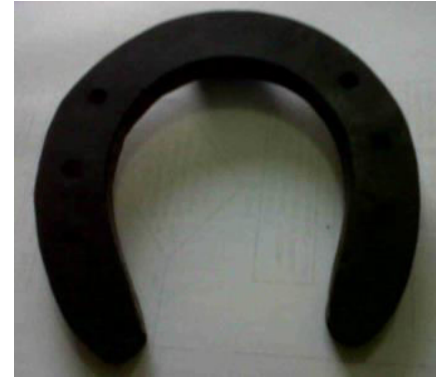

Gambar 6. Tampak Bawah Hasil Modifikasi Sepatu Kuda Setelah Di Lapisi Karet (Setelah Dilakukan Finishing)

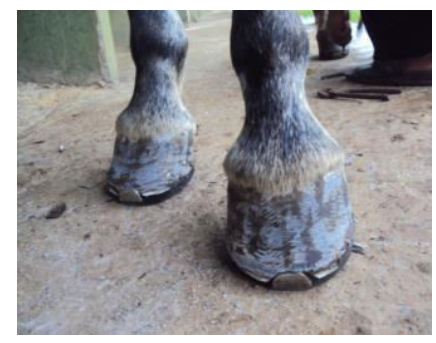

Gambar 7. Tampak Depan Hasil Modifikasi Sepatu Kuda Setelah Di Pasang Pada Kaki Kuda

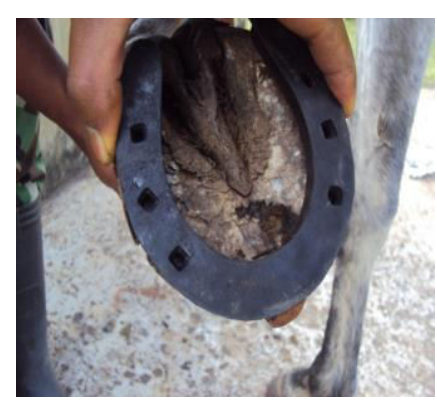

Gambar 8. Tampak Belakang Hasil Modifikasi Sepatu Kuda Setelah Di Pasang Pada Kuda

\section{Pembahasan Modifikasi Sepatu Kuda}

- Pengujian dinamis

Berikut hasil pengujian dinamis modifikasi sepatu kuda dengan pengait. Pada pengujian dinamis telah dilaksanakan selama satu hari penuh dijalankan mengelilingi Asrama Yonkav 3/Tank di Singosari. Pada pengujian tersebut diperoleh hasil ketahanan kikis sebagai berikut:

Tabel 1. Pengolahan Data Hasil Rata-Rata Pengujian Dinamis

\begin{tabular}{clccccc}
\hline \multirow{2}{*}{ No } & Posisi Sepatu & \multicolumn{4}{c}{ Pengukuran Ketebalan Pada Jarak Yang } & $\begin{array}{c}\text { Rata-Rata } \\
\text { Ditempuh }(\mathbf{m m})\end{array}$ \\
\cline { 3 - 6 } & & $\mathbf{0 ~ k m}$ & $\mathbf{5} \mathbf{~ k m}$ & $\mathbf{1 0} \mathbf{~ k m}$ & $\mathbf{1 5} \mathbf{~ k m}$ & $\mathbf{k m}$ \\
\hline 1 & Kanan Depan & 10.98 & 10.94 & 10.90 & 10.86 & 0.0080 \\
2 & Kiri Depan & 10.98 & 10.94 & 10.90 & 10.86 & 0.0080 \\
3 & Kanan Belakang & 11.02 & 10.96 & 10.92 & 10.88 & 0.0093 \\
4 & Kiri Belakang & 10.98 & 10.94 & 10.90 & 10.86 & 0.0080 \\
\hline \multicolumn{5}{c}{ Rata-Rata } \\
\hline
\end{tabular}

Cara untuk menghitung laju pengikisan karet per hari dapat dihitung dengan cara dibawah ini :

$=$ Rata-rata Keausan sepatu kuda $\times$ Jarak tempuh dalam 1 hari

$=0,0083 \mathrm{~mm} / \mathrm{km} \times 15 \mathrm{~km}=0,125 \mathrm{~mm}$

Umur pakai sepatu dengan lapisan karet dapat dihitung dengan persamaan berikut :

$$
\text { Umur }=\frac{\text { Ketebalan lapisan karet }}{\text { Laju pengikisan / hari }}
$$$$
=\frac{4,5 \mathrm{~mm}}{0,125 \mathrm{~mm} / \text { hari }}=36 \text { hari }
$$

Dari perhitungan yang dilakukan diatas telah diketahui bahwa rata-rata pengikisan yang terjadi pada sepatu kuda adalah sebesar $0,125 \mathrm{~mm} / 15 \mathrm{~km}$. Dengan ketebalan lapisan karet pada sepatu kuda 4,5 mm, maka umur pemakaian yang didapat selama 36 hari. Apabila plat baja yang ada ditanam dalam 
sepatu kuda sudah terlihat, maka sepatu kuda ini sudah tidak layak untuk dipakai.

\section{- Pengujian keausan}

Berikut hasil pengujian keausan bahan karet yang digunakan sebagai lapisan karet sepatu kuda dengan menambah pengait. Pengujian keausan karet telah dilaksanakan di Universitas Merdeka Malang. Pada pengujian tersebut diperoleh hasil keausan sebagai berikut:

Tabel 2. Data Hasil Pengujian Keausan

\begin{tabular}{ccccc}
\hline No & $\begin{array}{c}\text { Berat } \\
\text { awal }\end{array}$ & $\begin{array}{c}\text { Berat } \\
\text { akhir }\end{array}$ & $\begin{array}{c}\Delta \boldsymbol{W} \\
(\mathbf{g r})\end{array}$ & $\begin{array}{c}\text { Laju keausan } \\
(\mathbf{g r} / \mathbf{m})\end{array}$ \\
\hline 1 & 4,1 & 3,9 & 0,2 & $4,7 \times 10^{-4}$ \\
2 & 3,8 & 3,7 & 0,1 & $2,3 \times 10^{-4}$ \\
3 & 4,6 & 4,4 & 0,2 & $4,7 \times 10^{-4}$ \\
4 & 4,5 & 4,4 & 0,1 & $2,3 \times 10^{-4}$ \\
5 & 4,3 & 4,2 & 0,1 & $2,3 \times 10^{-4}$ \\
6 & 3,4 & 3,3 & 0,1 & $2,3 \times 10^{-4}$ \\
\hline
\end{tabular}

Laju keausan karet dapat dihitung dengan cara menentukan berat lapisan karet yang hilang selama pengujian keausan dilakukan. Lapisan karet tersebut akan berkurang berdasarkan jarak tempuh yang dicapai akibat gesekan yang terjadi. Perhitungan laju keausan dapat dilakukan dengan perhitungan sebagai berikut.

Perhitungan kecepatan keliling $(v)$ :

$v=\frac{\pi \cdot d \cdot n}{1000}=\frac{\pi \cdot 27.996}{1000}=84,4 \mathrm{~m} /$ menit

Maka untuk mencari jarak tempuh $(s)$ dengan lama waktu pengujian 5 menit adalah :

$s=v \cdot t=84,4$ meter $/$ menit $\times 5$ menit $=422$ meter.

Untuk mencari nilai laju keausannya:

$\dot{m}=\frac{\square w}{s}=\frac{0,2}{422}=4,7 \times 10^{-4} \mathrm{gr} / \mathrm{m}$
Dalam pengujian keausaun karet diatas perlu mencari rata-rata laju keausan karetnya dengan cara dibawah ini :

$=\frac{u j i 1+u j i 2+u j i 3+u j i 4+u j i 5+u j i 6}{\text { jumlah pengujian }}$

$=\frac{(4,7+2,3+4,7+2,3+2,3+2,3) \times 10^{-4}}{6}$

$=3,2 \times 10^{-4} \mathrm{gr} / \mathrm{m}$

Rata-rata laju keausan karet adalah $3.2 \mathrm{x}$ $10^{-4} \mathrm{gr} / \mathrm{m}$, untuk jarak tempuh kuda $15 \mathrm{~km} / \mathrm{hari}$ diperoleh besarnya keausan :

$=$ Rata-rata laju keausan $\times$ Jarak tempuh $/$ hari

$=3,2 \times 10^{-4} \mathrm{gr} / \mathrm{m} \times 15.000 \mathrm{~meter} / \mathrm{hari}$

$=4,65 \mathrm{gr} / \mathrm{hari}$

Jika sepatu kuda digunakan selama 36 hari, maka besar keausan selama 36 hari adalah $=4,65 \mathrm{gr} / \mathrm{hari} \times 36$ hari $=165,6$ gram

Jika berat jenis lapisan karet (Sutikno, 2011) adalah $\mathrm{BJ}=1,179 \mathrm{gram} / \mathrm{cm}^{3}$, maka untuk mencari nilai volume karet yang terkikis adalah sebagai berikut :

Volume $=\frac{\text { Berat }}{\text { Berat Jenis }}=\frac{165,6}{1,179}=140,5 \mathrm{~cm}^{3}$

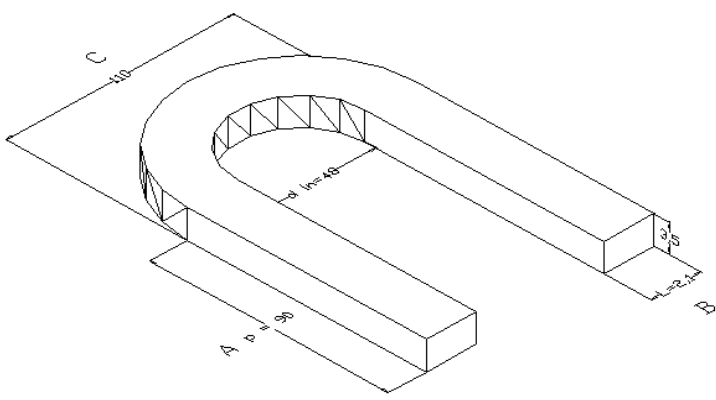

Gambar 9. Penampang Plat Sepatu Kuda

Volume bagian $\mathrm{A}=$ Volume bagian $\mathrm{B}$

$$
=P \times L \times t=9 \times 2,1 \times t=18,9 \mathrm{tcm}^{3}
$$


Volume bagian $\mathrm{C}$

$$
\begin{aligned}
& =\frac{1}{2} \times \frac{\pi}{4} \cdot\left(d_{\text {out }}{ }^{2}-d_{\text {in }}{ }^{2}\right) \cdot t \\
& =\frac{1}{2} \times \frac{\pi}{4} \cdot\left(11^{2}-4,8^{2}\right) \cdot t=38,45 \cdot t \mathrm{~cm}^{3}
\end{aligned}
$$

Volume total $=\operatorname{vol} \mathrm{A}+\operatorname{vol} \mathrm{B}+\operatorname{vol} \mathrm{C}$

$$
\begin{aligned}
& =(18,9+18,9+38,45) \cdot t \\
& =76,25 t \cdot \mathrm{cm}^{3}
\end{aligned}
$$

Maka ketebalan volume karet hilang sebesar $140,5 \mathrm{~cm}^{3}$ adalah

$$
\begin{aligned}
& 118,32 \mathrm{~cm}^{3}=76,25 \cdot t \mathrm{~cm}^{3} \\
& t=\frac{140,5}{76,25}=1,842 \mathrm{~cm}=18,42 \mathrm{~mm}
\end{aligned}
$$

Apabila ketebalan lapisan bawah karet sepatu kuda hanya 4,5 mm, maka umur pakai berdasarkan hasil pengujian keausan diperoleh:

$$
\begin{aligned}
& =\frac{\text { tebal lapisan karet }}{\text { ketebalan karet yang hilang }} \times 36 \text { hari } \\
& =\frac{4,5 \mathrm{~mm}}{18,42 \mathrm{~mm}} \times 36 \text { hari }=8,8 \text { hari } \approx 9 \text { hari }
\end{aligned}
$$

Pengujian keausan menggunakan pembebanan sebesar $20 \mathrm{~kg}$. Untuk mengetahui kesebandingan dengan kondisi pembebanan aktual, maka diperlukan perhitungan tekanan kerja yang diterima oleh lapisan karet tersebut.

Menghitung beban sepatu kuda pada tiap kaki :

$$
W=\frac{380 \mathrm{~kg}}{4 k a k i}=95 \mathrm{~kg} / \mathrm{kaki}
$$

Tekanan yang bekerja pada luasan permukaan sepatu adalah

$$
P_{\text {aktual }}=\frac{95 \mathrm{~kg}}{76,25 \mathrm{~cm}^{2}}=1,25 \mathrm{~kg} / \mathrm{cm}^{2}
$$

Tekanan kerja pada specimen pengujian diperoleh dengan perhitungan berikut : Luas specimen uji $=2 \mathrm{~cm} \times 3 \mathrm{~cm}=6 \mathrm{~cm}^{2}$

$$
P_{u j i}=\frac{20 \mathrm{~kg}}{6 \mathrm{~cm}^{2}}=3,3 \mathrm{~kg} / \mathrm{cm}^{2} \quad \rightarrow \quad 2,67 \quad \text { kali }
$$

tekanan kerja pada permukaan sepatu. Maka umur dari sepatu kuda adalah :

$=9$ hari $\times 2,67$ kali $=24$ hari .

Setelah dilakukan pengujian dan pengolahan data maka dapat disimpulkan karet yang digunakan menjadi bahan sepatu kuda tersebut mempunyai daya tahan 24 hari dan berbeda dari hasil pengujian dinamisnya. Disebabkan karena selama pengujian keausan dilakukan alat uji kehausan terjadi panas akibat gesekan yang dapat mengakibatkan material uji karet meleleh. Hal ini akan menyebabkan hasil pengujian dinamis dengan pengujian keausan karet yang berbeda.

\section{Perhitungan secara analitis kekuatan konstruksi paku dan plat}

\section{- Analisa kekuatan paku}

Dalam analisa ini peneliti mengambil bahan paku Cast Iron yang digunakan dengan bentuk sebagai berikut :

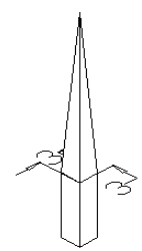

\section{Gambar 10. Bentuk Penampang Paku}

Dimana :

$$
\begin{aligned}
& \sigma_{\text {tarik }}=20 \mathrm{~kg} / \mathrm{mm}^{2} \text { (bahan Cast Iron) } \\
& \tau_{\text {geser ijin }}=0,45 \times 20 \mathrm{~kg} / \mathrm{mm}^{2}=9 \mathrm{~kg} / \mathrm{mm}^{2}
\end{aligned}
$$

Jadi gaya yang dibutuhkan untuk mematahkan paku adalah :

$$
\begin{aligned}
& F=\tau_{\text {geser ijin }} \times A \\
& F=9 \mathrm{~kg} / \mathrm{mm}^{2} \times 9 \mathrm{~mm}^{2}=81 \mathrm{~kg}
\end{aligned}
$$


Jika didalam sepatu kuda ada 6 buah paku yang bekerja bersamaan, maka gaya yang dibutuhkan untuk mematahkan ke 6 paku secara bersama-sama adalah :

$$
\begin{aligned}
& =\text { Jumlah paku } \times F=6 \text { buah } \times 81 \mathrm{~kg} \\
& =486 \mathrm{~kg}
\end{aligned}
$$

Pada kenyataan yang terjadi di lapangan dimana kondisi paku sepatu tidak pernah terjadi kegagalan patah, sehingga diasumsikan bahwa gaya aktual yang sebenarnya bekerja adalah $1 / 4$ dari beban sebenarnya : $\frac{1}{4} \times F_{x}=\frac{1}{4} \times$ $486 \mathrm{~kg}=121,5 \mathrm{~kg}$

\section{- Analisa kekuatan plat}

Untuk menganalisa kekuatan plat pada sepatu kuda, maka diperlukan untuk menentukan tekanan kerja (Ardilana, R. P., dkk., 2017) terlebih dahulu dengan cara dibawah ini.

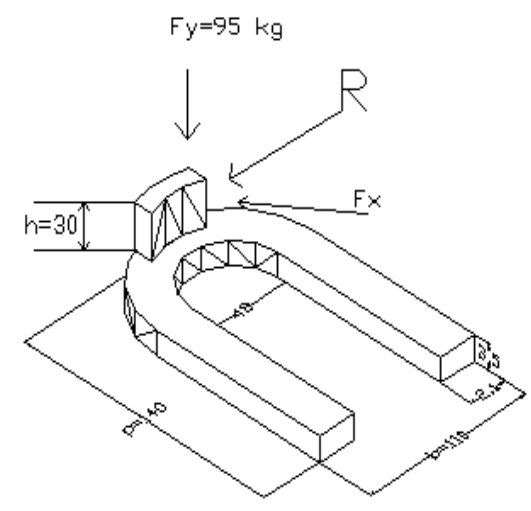

Gambar 11. Pemodelan Beban Pada Plat Sepatu Kuda

1. Tekanan $\left(P_{\text {kerja }}\right)$

$P_{\text {ker ja }}=\frac{W}{A}=\frac{95 \mathrm{~kg}}{76,25 \mathrm{~mm}^{2}}=1,25 \mathrm{~kg} / \mathrm{mm}^{2}$

Berdasarkan perhitungan tekanan yang diterima oleh plat akibat beban $F_{y}=W=95 \mathrm{~kg}$ dengan luasan penampang plat $A=76,25 \mathrm{~mm}^{2}$. Sehingga :
$P_{\text {kerja }} 1,25 \mathrm{~kg} / \mathrm{mm}^{2} \leq P_{i j i n} 8 \mathrm{~kg} / \mathrm{mm}^{2}$

2. Kekuatan geser (Fanawa, O. S., dkk., 2018)

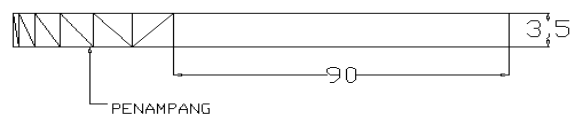

Gambar 12. Penampang Plat Sepatu Kuda

$\tau_{\text {geser }}=\frac{F_{y}}{A}=\frac{95 \mathrm{~kg}}{21 \times 3,5}=1,29 \mathrm{~kg} / \mathrm{mm}^{2}$

Berdasarkan perhitungan kekuatan geser yang diterima oleh plat akibat beban $F_{y}=W=$ $95 \mathrm{~kg}$ dengan luasan penampang plat $A=1,29$ $\mathrm{kg} / \mathrm{mm}^{2}$.

Sehingga :

$\tau_{\text {geser }}\left(1,29 \mathrm{~kg} / \mathrm{mm}^{2}\right) \leq \tau_{\text {geserijin }}\left(27 \mathrm{~kg} / \mathrm{mm}^{2}\right)$

3. Tegangan lentur

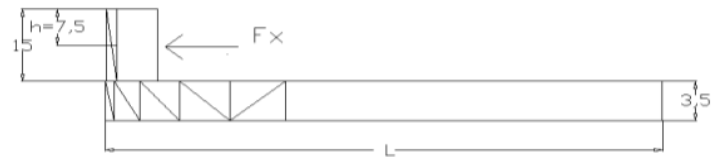

Gambar 13. Penampang Plat Sepatu Kuda

Tegangan lentur yang terjadi dapat dihitung dengan persamaan berikut (Supriyanto, Y., dkk., 2018) :

$$
\sigma_{\text {lentur }}=\frac{M . c}{I}
$$

Untuk menentukan nilai rumus diatas dapat dilihat di bawah ini :

$$
\begin{aligned}
M & =F_{x} \cdot h=121,5 \mathrm{~kg} \times 7,5 \mathrm{~mm} \\
& =911,25 \mathrm{~kg} \cdot \mathrm{mm} \\
c & =1,75 \mathrm{~mm} \\
I & =\frac{h \cdot t^{3}}{12}=\frac{30 \times 3,5^{3}}{12}=107,2 \mathrm{~mm}^{4}
\end{aligned}
$$

Maka :

$$
\begin{aligned}
\sigma_{\text {lentur }} & =\frac{911,25 \mathrm{~kg} \cdot \mathrm{mm} \times 1,75 \mathrm{~mm}}{107,2 \mathrm{~mm}^{4}} \\
& =14,87 \mathrm{~kg} / \mathrm{mm}^{2}
\end{aligned}
$$


$\sigma_{\text {lentur }}$ yang terjadi $14,87 \mathrm{~kg} / \mathrm{mm}^{2} \leq \sigma_{\text {lentur ijin }} 24$ $\mathrm{kg} / \mathrm{mm}^{2}$

\section{SIMPULAN}

Pada penelitian ini, dapat diperoleh kesimpulan sebagai berikut :

1. Pada pengujian dinamis, telah didapatkan prediksi umur sepatu kuda yang sudah dimodifikasi dengan pengait yaitu 36 hari. Laju keausan pada pengujian dinamis terdapat rata-rata pengikisan sebesar 0,125 mm/15 km (dalam 1 hari). Sehingga pada pemakaian selama 36 hari terjadi pengikisan sebesar 4,5 $\mathrm{mm}$.

2. Pada pengujian keausan, telah didapatkan prediksi umur sepatu kuda yang sudah dimodifikasi dengan pengait yaitu 24 hari.

Pada pengujian keausan didapat rata-rata laju keausan karet $3,2 \times 10^{-4} \mathrm{gr} / \mathrm{m}$. Untuk jarak tempuh kuda $15 \mathrm{~km} / \mathrm{hari}$ maka ratarata laju keausan yang terjadi 4,65 gr/hari.

\section{DAFTAR PUSTAKA}

Abednego J. G., 1980, Pengetahuan Praktis Mengenai Barang Jadi Karet, Bogor

Abednego J.G., 1980, Bahan Kimia Pembuatan Kompon, Bogor

Anonimous, 2005, Naskah Detasemen Kaveleri Berkuda Tentang Pengetahuan Kuda

Ardilana, R. P., Sufiyanto, S., Ardiyanto, A., 2017, Analisa Struktur Rangka Dudukan Winch Pada Salute Gun 75 mm Winch System, Transmisi, Vol. 13 No. 1, Jurusan Teknik Mesin, Fakultas Teknik, Universitas Merdeka Malang.
Fanawa, O. S., Sufiyanto, S., Rohman, J., 2018, Analisa Gaya Recoil Dan Desain Komponen Popor Corner Shot Pada Pistol P1 Pindad Kaliber 9 mm, Transmisi, Vol. 14 No. 1, Jurusan Teknik Mesin, Fakultas Teknik, Universitas Merdeka Malang.

ISO 37, 1994, Rubber Vulcanized or Thermoplastic-Determination at Tensile Stress-Strain Properties

ISO 4649,1990 Rubber - Determination Of Abrasion Resistance Using A Rotating Cylinder Drum Device

ISO 1417, 1991, Rubber-Measurement of Vulkaniztion Characteristics With The Oscillating Disc Curemeter

ISO 816, 1983, Rubber, Vulcanized Determination of Tear Strength of Small Test Pieces

SNI 0788, 2009, Sol Karet Cetak, Jakarta

Supriyanto, Y., Sufiyanto, S., Kusnadi, K., 2018, Desain Mecanum Wheel System Pada Kendaraan Robot Tempur Kota, Transmisi, Vol. 14 No. 2, Jurusan Teknik Mesin, Fakultas Teknik, Universitas Merdeka Malang.

Sutikno, 2011, Analisa Bahan Pengganti Karet Sepatu Kuda Pada Kuda Denkavkud, Malang.

Thomas Julius, Teknologi Barang Jadi Karet. Bogor 